anales de psicología / annals of psychology

2019, vol. 35, no 2 (may), 188-194

http://dx.doi.org/10.6018/analesps.35.2.336941
(C) Copyright 2019: Editum. Servicio de Publicaciones de la Universidad de Murcia. Murcia (Spain) ISSN print edition: 0212-9728. ISSN on line edition (http://revistas.um.es/analesps): 1695-2294.

On line edition License Creative Commons 4.0: BY-NC-ND

\title{
Coping strategies and self-esteem in women with breast cancer
}

\author{
Miriam Joaquín-Mingorance ${ }^{1, *}$, Félix Arbinaga ${ }^{1}$, José Carmona-Márquez ${ }^{1}$, and Juan Bayo-Calero ${ }^{2}$ \\ 1 Department of Clinical \& Experimental Psychology. University of Huelva (Spain) \\ 2 Hospital Juan Ramón Jiménez, Huelva (Spain)
}

\begin{abstract}
Título: Estrategias de afrontamiento y autoestima en mujeres con cáncer de mama.

Resumen: El afrontamiento del diagnóstico de cáncer de mama y el uso de diferentes estrategias es clave para superar esta situación estresante. Diversas variables psicológicas están relacionadas con la manera de afrontar la enfermedad, destacando entre ellas la autoestima. Se analiza la influencia que la edad, de las pacientes con cáncer de mama, pueda tener en las estrategias de afrontamiento ante la enfermedad, analizando si la autoestima influye en el uso de las estrategias y observar la posible interrelación entre estas variables. Se evalúa la autoestima mediante Rosenberg Self-Steem Scale y las estrategias de afrontamiento con la escala COPE-28, en sus versiones españolas. La muestra estaba formada por 121 mujeres, con cáncer de mama, y edades entre los 30 y los 77 años $(M=49.33, D T=8.90)$. Los resultados muestran que el afrontamiento activo fue la estrategia más utilizada. Se encontraron relaciones significativas, mediadas por la edad, entre las puntuaciones en autoestima y las estrategias de afrontamiento activas, como son la reevaluación positiva, aceptación o el apoyo emocional. Conocer la manera de afrontar la enfermedad ayudará en el desarrollo de interven ciones psicológicas que mejoren la calidad de vida de estas pacientes durante todo el proceso de enfermedad oncológica.

palabras clave: Psicooncología; estrategias psicológicas; afrontamiento ac tivo; reevaluación positive.
\end{abstract}

\section{Introduction}

The diagnosis of breast cancer is a stressful event that causes psychological distress (Hamama-Raz, 2012; Pereira, Figueiredo \& Fincham, 2012; Kangas, 2013). Women undergoing cancer treatment have to face a variety of potentially stressful situations, and it has been shown that mastectomised women have a lower level of self-esteem and a more negative body image than women undergoing conservative surgeries, with significant differences between self-esteem scores according to the type of surgical intervention (Segura, García \& Saúl, 2014). Alopecia induced by chemotherapy represents the most distressing side effect of chemotherapeutic agents and is of great concern for most patients, negatively affecting their mood and self-esteem (Dunnill, AlTameemi, Collett, Haslam \& Georgopoulos, 2018). Other symptoms such as frequent and intense fatigue, and sleep disturbances that increase progressively throughout the chemotherapy treatment (Henneghan, Carter, Stuifbergan, Parmelee \& Kesler, 2018) usually affect patients with breast cancer, in addition to frequent and intense emotional disturbances such as anxiety (Yang et al., 2016) and depression (García-Torres \& Alós, 2013).

* Correspondence address [Dirección para correspondencia] Miriam Joaquin-Mingorance. Calle Alhelí No40 Lepe, Huelva (Spain).

E-mail: miriamjoaquin20@gmail.com

(Article received: 10-07-2018; revised: 06-11-2018; accepted: 23-11-2018)
Abstract: Coping with a breast cancer diagnosis and the use of different strategies is key to overcoming this stressful situation. Various psychological variables are related to how patients cope with the disease, one of which is self-esteem. The current study analyses the how age influences patients with breast cancer in terms of the coping strategies used to deal with the disease, exploring whether self-esteem influences the use of such strategies, along with the possible interrelation between these variables. Self-esteem is studied using the Rosenberg Self-Esteem scale and coping strategies were assessed using the COPE-28 scale, both in their Spanish versions. The sample consisted of 121 women (with breast cancer), aged between 30 and 77 years $(M=49.33, S D=8.90)$. The results indicate that active coping is the strategy with the highest score. We found significant, age-mediated relationships between self-esteem scores and active coping strategies such as positive reframing, acceptance, or use of emotional support. Knowing how to cope with the disease will help in the development of psychological interventions that improve the quality of life in these patients throughout the oncological disease process.

Keywords: Psycho-Oncology; psychological strategies; active coping; positive reframing. these situations (Hopman \& Rijken, 2014). According to their consequences, the strategies can be categorised as being either more or less adaptive (Figueroa, Contini, Lacunza, Levín \& Suedan, 2005).

Coping strategies such as avoidance (Lan, L. Zhang, Y, Zhang \& Yan, 2018), repression (Cardona, Jaramillo \& Díaz, 2013), passive coping (Vargas, Herrera, Rodríguez \& Sepúlveda, 2011), self-blaming (Teo, Fingeret, Liu \& Chang, 2016), acceptance (Browall, Kenne, Persson, Wengström \& Gaston-Johansson, 2016) and ruminative thoughts (González, Ibáñez \& Barrera, 2017), are all generally considered to be less adaptive. When faced with a cancer diagnosis, it has been found that these strategies predicted a greater number of depressive symptoms and lower self-esteem (Cieslak \& Golusinski, 2018). When a person develops coping strategies that are mainly of the avoidant type, such as denial, the absence of positive reframing, or self-blaming —all of which are associated with a low quality of life - they usually present emotional states that make it difficult to directly address the stressful event (Brunault et al., 2016).

In contrast, strategies such as positive reframing (Ortiz et al., 2014), problem solving, and coping based on religion (Park, Waddington \& Abraham, 2018), which are generally considered more adaptive, are associated with a higher quality of life (Finck, Barradas, Zenger \& Hinz, 2018), a minor alteration of mood (Ringwald et al., 2016), fewer depressive symptoms (Avis, Levine, Naughton, Case \& Naftalis, 2013) and a higher level of self-esteem (Ortiz et al., 2014). These 
more adaptive coping strategies are related to greater psychological wellbeing (Danhauer et al., 2013).

The most frequently observed adaptive strategies are characterized by being active and focused on the problem (Cao, Qi, Cai \& Han, 2018), the most notable of these being positive reframing and personal growth, active coping and planning, followed by the use of religious beliefs (GraneroMolina et al., 2014), acceptance, and social support (Cardenal \& Cruzado, 2014). It has been observed that the majority of women present an active coping style, helping them to carry out activities that are enjoyable such as reading, walking, or physical exercise (Falo, Villar, Rodríguez, Mena \& Font, 2014).

These adaptive strategies tend to be associated with variables such as self-esteem, optimism (Dumalaon-Canaria, Prichard, Hutchinson \& Wilson, 2018) and family support, all of which are variables that intervene and influence the quality of life of cancer patients, particularly those with breast cancer (Eun \& Young, 2014). This quality of life can be affected by various risk factors in patients with breast cancer, these factors being mainly individual variables such as younger age, and less use of active coping, acceptance, or coping based on religion (Brunault et al., 2016; Elumelu, Asuzu \& Akin-Odanye, 2015). High scores in self-esteem have shown to be mediators in coping and adaptability in mastectomised women (Gómez, Bragado \& Hernández, 2014). Thus, a radical mastectomy is associated with an increase in depressive symptomatology (Sun, Ang, Darryl \& López, 2018), alterations in body image (Phillips \& McAuley, 2015) and low self-esteem (Pintado, 2017).

Finally, age is an aspect to be assessed when analysing the diagnosis of breast cancer, with a younger age being consistently associated with a greater negative impact of the diagnosis. Conversely, at an older age, an association with a more adaptive and positive coping style is usually observed (Boyle, Stanton, Ganz \& Bower, 2017). Younger women are more concerned about their family, economic, or work responsibilities (Rosen, Rodriguez-Wallberg \& Rosenzweig, 2009), which, among other issues leads to more problematic coping.

The present work aims to: 1 . Explore the possible influence of age on coping psychologically with breast cancer, 2 . Describe the coping strategies developed by women based on their self-esteem scores, and 3. Analyse the relationship between age, self-esteem, and coping strategy.

The proposed hypotheses of this study were as follows:

- The most commonly used coping strategies will be active coping, acceptance, or positive reframing.

- Age influences the development of psychological coping strategies, such that the older the patient, the higher the likelihood of using more adaptive coping strategies.

- Women with high self-esteem scores will preferentially develop coping strategies of the following types: active coping, use of emotional support, social support, positive reframing, acceptance, and humour.

\section{Method}

\section{Participants}

The sample consisted of 121 women, aged between 30 and 77 years $(M=49.33, S D=8.90)$.

The average time that had elapsed since the cancer diagnosis was 50.75 months $(S D=60.91)$. Of the total sample, $115(95 \%)$ women had undergone a mastectomy compared with $6(5 \%)$ who had not. The mean time period since the mastectomy was 45.07 months $(S D=57.67)$. Regarding the type of treatment received, 51 women $(42.1 \%)$ had received chemotherapy, $18(14.9 \%)$ received radiotherapy, $42(34.7 \%)$ had undergone mixed treatment, $5(4.1 \%)$ had received hormonal therapy and $5(4.1 \%)$ had received other treatments.

\section{Instruments}

An ad hoc interview was administered in which participants were asked to give their age, establishing three groups (a: 30-45 years, b: 46-52 years and c: $>53$ years), along with variables related to the disease (time that had elapsed since the diagnosis (in months), type of intervention (mastectomy / no mastectomy), time that had elapsed since the intervention (in months), type of treatment), and marital status (single, living independently; single, living with someone; in a non-cohabiting partnership; living with partner, divorced, or widow).

To assess the coping strategies presented by the patients, the COPE-28 (Morán, Landero \& González, 2010) was used, in its version adapted to Spanish the Brief COPE scale (Carver, 1997). This scale presents a total of 28 items, which are answered on a Likert scale using 4 response alternatives (Not at all, A little, Fairly and Very much). The instrument evaluates the following main coping strategies: active coping (initiating direct actions to eliminate or reduce the stressor), planning (thinking about how to cope with the stressor, and planning strategies), use of emotional support (getting emotional support, understanding), use of social support (receiving help and advice from others), religion (tendency to turn to religion in times of stress), positive reframing (looking for positive aspects of the problem and trying to improve or grow from the situation), acceptance (accept the facts of what is happening, and that they are real), denial (denying the reality of the stressful event), humour (laughing at the situation), self-distraction (attempting to become distracted by other activities to avoid focusing on the stressor), selfblaming (blaming oneself for the situation), behavioural disengagement (reducing efforts to deal with the stressor), venting (tendency to express feelings of emotional distress) and substance use (consuming alcohol or other substances to feel good or to help in dealing with the stressor). The reliability coefficient of the scale, assessed using Cronbach's alpha, was acceptable, with $\alpha=.758$, in accord with the assumptions of George \& Mallery (2003, p.231). 
In addition, the Rosenberg Self-Esteem Scale (Rosenberg, 1965) was used to measure self-esteem in its Spanish version, which has been validated for the clinical population (Vázquez, Jiménez \& Vázquez-Morejón, 2004). This test, of a one-dimensional nature, is composed of a total of 10 items, whose answers are provided on a Likert-type ordinal scale, with 4 alternative answers $(1=$ Strongly agree, $2=$ Agree, 3 $=$ Disagree, $4=$ Totally disagree). Half of the items are stated positively (items from 1 to 5) and the other half negatively (items from 6 to 10), obtaining a total score of between 10 and 40 .

The results can be grouped into three categories (Rosenberg, 1965): low self-esteem (scores less than 25), average self-esteem (scores between 26 and 29), and high self-esteem (scores between 30 and 40). The scale has an acceptable internal consistency value $(a=.889)$.

\section{Procedure}

The criteria for inclusion in the sample included being a woman, presenting a diagnosis of breast cancer, not presenting any diagnosed psychological disorders, having completed the chemotherapy treatment, and being in the review phase of the disease. Following a review of the medical records and after checking that they met the inclusion criteria, contact was made with the patients in individual sessions following their corresponding oncological review consultation. The format of the tests was paper-pencil and they were always advised by a trained psychologist. In addition, patients were informed about the main objectives of the study, along with the anonymity and confidentiality of the data provided, the willingness to participate in the study, as well as the right to access, rectify, or withdraw the data in relation to their responses. The evaluations were carried out in the Oncology Unit of the Juan Ramón Jiménez Hospital in Huelva, Spain.

The study was approved by the Bioethics Committee of the University and by the Andalusian Betuaria Foundation for Health Research (FABIS). All the procedures followed comply with the ethical standards of the committee responsible for human experimentation (institutional and national) and the 1975 Declaration of Helsinki, as revised in 2000. The written informed consent of all the participants was obtained.

\section{Data analysis}

The analyses conducted were based on descriptive statistics (means, standard deviations, and percentages). For the study of the relationships between quantitative variables and categorical variables with more than two groups, an ANOVA was conducted, with Tukey's tests as post hoc and $\eta^{2} \mathrm{p}$ comparisons as measures of effect size. Finally, with the intention of evaluating the explanatory and predictive capacity of the self-esteem and age variables for the various coping strategies, a linear regression analysis was carried out.

\section{Results}

Among the main characteristics related to the oncological disease, it was found that the mean time elapsed since the women were diagnosed with breast cancer was 50.75 months $(S D=60.91)$, and the mean time since the mastectomy was 45.07 months $(S D=57.66)$.

When observing the strategies used for coping with the cancer diagnosis, the one that showed the highest score among the patients was active coping $(M=6.17, S D=$ 1509); conversely, the coping strategy with the lowest score was the use of substances $(M=2.66, S D=1.179)$.

When analysing coping strategies between the three age groups established in the study (a: 30-45 years, b: 46-52 years and $\mathrm{c}:>53$ years), it was found that age determines the use of active coping strategies such as acceptance $(F(2,120)=$ $4.708, p=.011)$ and humour $(F(2,120)=4.062, p=.020)$. In the corresponding post hoc analyses, Tukey's test revealed that these differences according to the age groups are significant between $\mathrm{b}$ and $\mathrm{c}$, with $\mathrm{b}>\mathrm{c}(p=.007)$ for acceptance, and also, $\mathrm{b}>\mathrm{c}(p=.019)$ for humour. No differences were established in the development of coping strategies according to marital status (Active coping $(F(5,120)=1.165, p=$ $.331)$; Planning $(F(5,120)=.574, p=.720)$; Use of emotional support $(F(5,120)=.580, p=.715)$; Social support $(F$ $(5,120)=.204, p=.960)$; Religion $(F(5,120)=1.660, p=$ $.150)$; Positive reframing $(F(5,120)=1.313, p=.264)$; Acceptance $(F(5,120)=.915, p=.474)$; Denial $(F(5,120)=$ $1.166, p=.330)$; Humour $(F(5,120)=2.156, p=.064)$; Selfmanagement $(F(5,120)=.218, p=.954)$; Self-blaming $(F$ $(5,120)=.661, p=.653)$; Behavioural disengagement $(F$ $(5,120)=.456, p=.808)$; Venting $(F(5,120)=1.334, p=$ $.255)$ and Substance use $(F(5,120)=.911, p=.477)$. 
Table 1. Coping strategies for dealing with the diagnosis (COPE-28) according to age groups.

\begin{tabular}{|c|c|c|c|c|c|c|c|c|c|}
\hline \multicolumn{10}{|c|}{ Age } \\
\hline & \multicolumn{2}{|c|}{$\begin{array}{l}30 \text { to } 45 \text { years } \\
\text { (a) }\end{array}$} & \multicolumn{2}{|c|}{$\begin{array}{l}46 \text { to } 52 \text { years } \\
\text { (b) }\end{array}$} & \multicolumn{2}{|c|}{$\begin{array}{c}\geq 53 \text { years } \\
\text { (c) }\end{array}$} & \multirow[b]{2}{*}{$F_{(2,120)}$} & \multirow[b]{2}{*}{$p$} & \multirow[b]{2}{*}{$\eta^{2}$} \\
\hline & $M$ & $S D$ & $M$ & $S D$ & $M$ & $S D$ & & & \\
\hline Active coping & 6.30 & 1.525 & 6.48 & 1.284 & 5.72 & 1.648 & 2.868 & .061 & .046 \\
\hline Planning & 5.73 & 1.017 & 5.75 & 1.143 & 5.25 & 1.080 & 2.740 & .069 & .044 \\
\hline Emotional support & 5.78 & 1.701 & 5.93 & 1.336 & 5.87 & 1.666 & .090 & .914 & .001 \\
\hline Social support & 5.51 & 1.483 & 5.68 & 1.156 & 5.62 & 1.442 & .169 & .845 & .002 \\
\hline Religion & 4.57 & 1.893 & 4.30 & 2.052 & 4.10 & 2.060 & .524 & .594 & .008 \\
\hline Positive reframing & 5.22 & 1.973 & 5.61 & 1.919 & 5.37 & 1.930 & .433 & .649 & .007 \\
\hline Acceptance & 5.94 & 1.352 & 6.38 & 1.261 & 5.45 & 1.568 & 4.708 & .011 & .073 \\
\hline Denial & 4.00 & 1.615 & 3.52 & 1.422 & 4.05 & 1.535 & 1.544 & .218 & .025 \\
\hline Humour & 3.73 & 1.502 & 4.35 & 1.495 & 3.50 & 1.320 & 4.062 & .020 & .025 \\
\hline Self-distraction & 4.94 & 1.373 & 5.41 & 1.419 & 4.92 & 1.575 & 1.479 & .232 & .024 \\
\hline Self-blaming & 3.30 & 1.525 & 3.43 & 1.420 & 3.77 & 1.576 & 1.047 & .354 & .024 \\
\hline Disengagement & 3.35 & 1.602 & 3.20 & 1.772 & 3.27 & 1.648 & .077 & .926 & .001 \\
\hline Venting & 4.40 & 1.423 & 4.77 & 1.444 & 4.60 & 1.565 & .620 & .540 & .010 \\
\hline Substance use & 2.65 & 1.206 & 2.73 & 1.282 & 2.60 & 1.032 & .125 & .883 & .002 \\
\hline
\end{tabular}

As the results in Table 2 show, there is a relationship between the different scores obtained in self-esteem and the use of each of the coping strategies. The self-esteem scores were grouped into low self-esteem ( $\mathrm{a}=<25$ points), average self-esteem ( $b=26-29$ points) and high self-esteem ( $c=30$ 40 points). Women with high self-esteem scores reported the use of more active coping strategies $(F(2,120)=6.955, p=$ $.001)$, with differences between $\mathrm{c}$ and $\mathrm{a}(p=.016)$, and $\mathrm{c}>\mathrm{b}$ $(p=.020)$. This same relationship is observed in the strategies based on the acceptance of the oncological diagnosis $(F$ $(2,120)=11.433, p<.001)$ where $\mathrm{c}>\mathrm{a}(p=.024), \mathrm{c}>\mathrm{b}(p=$ $.017)$ and positive reframing of the situation $(F(2,120)=$ 6.711, $p=.002)$ where $\mathrm{c}>\mathrm{a}(p=.001)$ and $\mathrm{c}>\mathrm{b}(p=.002)$.
When faced with a cancer diagnosis, receiving emotional support and the understanding and comfort of others appears to be significantly related to self-esteem, with these strategies being more likely to appear in those patients with high scores on self-esteem $(F(2,120)=6.252, p=.003)$. In the post hoc analyses these differences were shown to occur between the following self-esteem groups: $\mathrm{c}>\mathrm{a}(p=.010)$ and $\mathrm{c}>\mathrm{b}(p=.071)$. On the other hand, the women with low self-esteem score use, to a lesser extent, strategies based on social support $(F(2,120)=4.099, p=.019)$, the score on this strategy differing between self-esteem groups as follows: $\mathrm{c}>\mathrm{b}(p=.063)$.

Table 2. Strategies for coping with the diagnosis (COPE-28) based on self-esteem scores (Rosenberg-EAR Self-Esteem Scale).

\begin{tabular}{|c|c|c|c|c|c|c|c|c|c|}
\hline & \multicolumn{2}{|c|}{$\begin{array}{l}\text { Self-esteem } \\
\text { Low (a) }\end{array}$} & \multicolumn{2}{|c|}{$\begin{array}{c}\text { Self-esteem } \\
\text { Moderate (b) }\end{array}$} & \multicolumn{2}{|c|}{$\begin{array}{c}\text { Self-esteem } \\
\text { High (c) }\end{array}$} & \multirow[b]{2}{*}{$F_{(2,120)}$} & \multirow[b]{2}{*}{$p$} & \multirow[b]{2}{*}{$\eta^{2}$} \\
\hline & $M$ & $S D$ & $M$ & $S D$ & $M$ & $S D$ & & & \\
\hline Active coping & 5.00 & 1.414 & 5.28 & 1.489 & 6.40 & 1.435 & 6.955 & .001 & .105 \\
\hline Planning & 5.33 & 1.322 & 5.00 & 0.679 & 5.68 & 1.108 & 2.675 & .073 & .043 \\
\hline Emotional support & 4.55 & 1.130 & 5.14 & 1.292 & 6.09 & 1.540 & 6.252 & .003 & .096 \\
\hline Social support & 4.88 & 1.536 & 4.92 & 1.141 & 5.78 & 1.318 & 4.099 & .019 & .065 \\
\hline Religion & 5.33 & 1.224 & 4.35 & 2.239 & 4.21 & 2.011 & 1.300 & .276 & .022 \\
\hline Positive reframing & 3.55 & 1.943 & 4.00 & 1.358 & 5.78 & 1.817 & 11.433 & $<.001$ & .162 \\
\hline Acceptance & 4.88 & 1.536 & 5.07 & 1.328 & 6.16 & 1.367 & 6.711 & .002 & .102 \\
\hline Denial & 4.44 & 1.666 & 4.35 & 1.645 & 3.71 & 1.485 & 1.865 & .159 & .031 \\
\hline Humour & 3.55 & 1.236 & 3.00 & 1.176 & 4.04 & 1.498 & 3.406 & .036 & .055 \\
\hline Self-distraction & 4.44 & 1.236 & 4.85 & 1.791 & 5.20 & 1.428 & 1.347 & .264 & .022 \\
\hline Self-blaming & 4.33 & 1.322 & 3.78 & 1.625 & 3.38 & 1.489 & 1.930 & .150 & .032 \\
\hline Disengagement & 4.00 & 1.732 & 3.50 & 1.344 & 3.17 & 1.699 & 1.162 & .317 & .019 \\
\hline Venting & 4.55 & 1.424 & 3.64 & 1.215 & 4.74 & 1.473 & 3.573 & .031 & .057 \\
\hline Substance use & 2.77 & 1.092 & 2.78 & 1.251 & 2.63 & 1.178 & 0.150 & .861 & .003 \\
\hline
\end{tabular}

When analysing the correlations between the self-esteem scores and the coping strategies used, it is possible to observe (Table 3) that the strategies most strongly correlated with self-esteem are those that are more active and adaptive, particularly positive reframing $(r=.502, p<.001)$, use of emotional support $(r=.423, p<.001)$, active coping $(r=$ $.421, p<.001)$, social support $(r=.371, p<.001)$, acceptance $(r=.342, p<.001)$ and planning $(r=.280, p=.001)$.

In contrast, passive and less adaptive coping strategies, such as denial $(r=-.229, p=.006)$, behavioural disengage- 
ment $(r=-.212, p=.010)$ and self-blaming $(r=-.194, p=$ .017), correlate inversely and significantly with self-esteem. Thus, women with a lower self-esteem score deal with their cancer by denial of the disease and by blaming themselves for its development.

Table 3. Regression model taking age and self-esteem score as predictor variables (Rosenberg Self-Esteem Scale) for coping strategies (COPE-28).

\begin{tabular}{|c|c|c|c|c|c|c|}
\hline & & $r$ & $p$ & $\beta$ & $\Delta R^{2}$ & $p$ \\
\hline \multirow[t]{2}{*}{ Active coping } & Age & -.133 & .073 & -.133 & & .146 \\
\hline & Self-esteem & .421 & $<.001$ & $.438^{*}$ & .190 & $<.001$ \\
\hline \multirow[t]{2}{*}{ Planning } & Age & -.144 & .057 & -.144 & & .114 \\
\hline & Self-esteem & .280 & .001 & $.298 *$ & .088 & .001 \\
\hline \multirow[t]{2}{*}{ Emotional support } & Age & .065 & .238 & .065 & & .477 \\
\hline & Self-esteem & .423 & $<.001$ & $.420 *$ & .175 & $<.001$ \\
\hline \multirow[t]{2}{*}{ Social support } & Age & .093 & .154 & .093 & & .308 \\
\hline & Self-esteem & .371 & $<.001$ & .365 & .132 & $<.001$ \\
\hline \multirow[t]{2}{*}{ Religion } & Age & -.114 & .107 & -.114 & & .214 \\
\hline & Self-esteem & -.143 & .058 &.-133 & .018 & .146 \\
\hline \multirow[t]{2}{*}{ Positive reframing } & Age & .075 & .208 & .075 & & .415 \\
\hline & Self-esteem & .502 & $<.001$ & $.500 *$ & .247 & $<.001$ \\
\hline \multirow[t]{2}{*}{ Acceptance } & Age & -.142 & .060 & -.142 & & .120 \\
\hline & Self-esteem & .342 & $<.001$ & $.360 *$ & .128 & $<.001$ \\
\hline \multirow[t]{2}{*}{ Denial } & Age & 0.59 & .260 & .059 & & .519 \\
\hline & Self-esteem & -.229 & .006 &.$-237^{*}$ & .056 & .009 \\
\hline \multirow[t]{2}{*}{ Humour } & Age & -.128 & .081 & -.128 & & .161 \\
\hline & Self-esteem & .134 & .071 &. .149 & .022 & .104 \\
\hline \multirow[t]{2}{*}{ Self-distraction } & Age & .007 & .471 & .007 & & .941 \\
\hline & Self-esteem & .172 & .030 & .173 & .030 & .060 \\
\hline \multirow[t]{2}{*}{ Self-blaming } & Age & .149 & .051 & .149 & & .102 \\
\hline & Self-esteem & -.194 & .017 & $-.211 * *$ & .044 & .020 \\
\hline \multirow[t]{2}{*}{ Disengagement } & Age & -.030 & .370 & -.030 & & .741 \\
\hline & Self-esteem & -.212 & .010 & $-.211 * *$ & .044 & .022 \\
\hline \multirow[t]{2}{*}{ Venting } & Age & .012 & .447 & .012 & & .894 \\
\hline & Self-esteem & .211 & .010 & $.211 * *$ & .044 & .021 \\
\hline \multirow[t]{2}{*}{ Substance use } & Age & -.044 & .316 & -.044 & & .632 \\
\hline & Self-esteem & -.149 & .051 & -.147 & .021 & .112 \\
\hline
\end{tabular}

${ }^{*} p<.001 ; * * p<.05$

Next, the predictive capacity of self-esteem with respect to each of the coping strategies was analysed, having controlled for the effect of age (Table 3). The results show that self-esteem increases the explanatory capacity of the model by $24.7 \%$ with respect to the age variable, when positive reframing is used as a coping strategy $(p<.001)(\beta=.500, p<$ $.001)$. And when emotional support is used as a strategy, $17.5 \%$ of the model is accounted for by self-esteem $(p<$ $.001)$, with a predictive capacity of $\beta=.420(p<.001)$. For coping based on social support, self-esteem increases the proportion of variance explained with respect to age by $13.2 \%(p<.001)$. A similar relationship can be observed when coping is based on the acceptance of cancer, thus increasing the proportion of variance explained by self-esteem by $12.8 \%(p<.001)(\beta=.360, p<.001)$ once age has been controlled. Self-esteem also increases the explanatory power of the use of planning strategies by $8.8 \%(p=.001)$ with respect to age, with a predictive value of $(\beta=.298, p<.001)$.

The less adaptive and passive coping strategies have a lower explanatory value, particularly denial, a strategy that explains only $5.6 \%$ of the variance $(p=.009)(\beta=-.237, p<$ .001).

\section{Discussion}

The aim of the study was to analyse the influence of age and self-esteem on the use of coping strategies used by female oncological patients with breast cancer. Active coping appears to be the strategy most used by these women, which is in accord with other observations in the literature (Dumalaon-Canaria, Prichard, Hutchinson \& Wilson, 2018; Finck, Barradas, Zenger \& Hinz, 2018; Ortiz, et al., 2014; Park, Waddington \& Abraham, 2018).

In terms of our first objective, which sought to determine the influence of the age of the patients on the strategies used to address the diagnosis and development of cancer, it was found that this variable has an impact on the development of such strategies. Thus, women between the ages of 46 and 52 were those with the highest scores on acceptance and humour strategies. In spite of data that appears to indicate a relationship between age and coping strategies (You, Wang, Rodríguez, Wang \& Lu, 2018, Brunault et al., 2016) in which younger people tend to use more emotionally-focused ways of coping (Compas et al., 1999), our findings reveal that it is the 46-52 year age group that is more strongly linked to the use of active coping strategies (acceptance, humour). 
Moreover, it was found that women who have high selfesteem scores are those who show a greater use of coping strategies of the following types: active coping, use of emotional support, social support, positive reframing, acceptance, humour and venting. In particular, it was observed that those patients diagnosed with breast cancer who had high selfesteem tend to face the oncological disease in a more active and positive way, showing a greater tendency to use active coping and positive reframing. These results support the findings of other related studies such as that of Ortiz et al. (2014) who reported a link between the use of adaptive strategies such as positive reframing and self-esteem (DumalaonCanaria, Prichard, Hutchinson \& Wilson, 2018).

When analysing the relationship between the variables of age, self-esteem, and coping strategies, it was observed how the inclusion of the self-esteem variable, when controlling for the age of the patients, increased the predictive capacity for the type of coping strategy used to face the disease. In a previous study, De Haro-Rodríguez et al. (2014) analysed the relationship between age and coping strategies, concluding that there was a negative relationship between age and strategies linked to problem-solving, social support, and positive reframing. However, they had not considered self-esteem scores to be a moderating factor in these patients, as shown in the results obtained in this work. However, Robert et al. (2010) showed that coping strategies such as religion are related to adjusting to the disease and maintaining adequate self-esteem, findings that are not confirmed in our work.
Therefore, the present findings make a novel contribution by revealing the impact of self-esteem - as an individual variable - on strategies for coping with breast cancer, along with finding that this is interrelated with the age variable.

As limitations of the study, it is important to emphasize that the design employed here does not allow for establishing the directionality or the causality of the relationships between self-esteem and coping strategies. Similarly, it is worth mentioning the transversal nature of this work, which does not allow us to identify how the use of coping strategies and selfesteem scores in these patients evolves throughout the development of the disease or with the advancement of age.

Future studies should approach this issue using larger sample sizes and in different conditions and stages of the disease. Moreover, it would be of interest to use designs that explore the role of other variables such as quality of life, use of pharmacological therapy and / or surgery, physical impact, alterations in body image, along with other consequences derived from the disease and its treatment, all of which can affect the way in which patients cope during the course of the disease.

Acknowledgements.- The authors wish to express their gratitude to the Oncology Unit of the Juan Ramón Jiménez Hospital in Huelva (Spain), thanking them for their participation in the development of the evaluations. We also thank the Andalusian Beturia Foundation for Health Research (FABIS) (Huelva) when authorizing the development of this study in the hospital complex.

\section{References}

Avis, N. E., Levine, B., Naughton, M. J., Case, L. D., \& Naftalis, E. (2013). Age-related longitudinal changes in depressive symptoms following breast cancer diagnosis and treatment. Breast Cancer Research Treatment, 139(1), 199-206. doi: 10.1007/s10549-013-2513-2

Browall, M., Kenne, S. E., Persson, L. O., Wengström, Y., \& GastonJohansson, F. (2016). Patient-reported stressful events and coping strategies in post-menopausal women with breast cancer. European Journal of Cancer Care, 25(2), 324-333. doi: 10.1111/ecc.12294

Brunault, P., Champagne, A. L., Huguet, G., Suzanne, I., Senon, J. L., Body, G., Rusch, E.,...Camus, V. (2016). Major depressive disorder, personality disorders, and coping strategies are independent risk factors for lower quality of life in non-metastatic breast cancer patients. PsychoOncology, 25(5), 513-520. doi:10.1002/pon.3947

Boyle, C. C., Stanton, A. N., Ganz, P. A., \& Bower, J. E. (2017). Posttraumatic growth in breast cancer survivors: does age matter?. PsychoOncology, 26(6), 800-807. doi: 10.1002/pon.4091

Cao, W., Qi, X., Cai, D. A., \& Han, X. (2018). Modeling posttraumatic growth among cancer patients: The roles of social support, appraisals, and adaptive coping. Psycho-Oncology, 27(1), 208-215. doi: 10.1002/pon. 4395

Cardenal, M. C., \& Cruzado, J. A. (2014). Estrategias de afrontamiento y malestar emocional en mujeres con resultados dudosos de su mamografía de cribado. Psicooncología, 11, (2), 285-299. doi: 10.5209/rev_PSIC.2014.v11.n2-3.47389

Cardona, E. J., Jaramillo, A. C., \& Díaz, V. E. (2013). Relación entre la personalidad tipo c y el cáncer. Psicoespacios: Revista Virtual de la Institución Universitaria de Envigado, 7(10), 66-92. doi: 10.25057/21452776.140

Carver, C. S. (1997). You want to measure coping but your protocol's too long: Consider the Brief COPE. International Journal of Behavioral Medicine, 4(1), 92-100. doi: 10.1207/s15327558ijbm0401_6

Cieslak, K., \& Golusinski, W. (2018). Coping with loss of ability vs. emotional control and self-esteem in women after mastectomy. Reports of Practical Oncology and Radiotherapy, 23(3), 168-174. doi: 10.1016/j.rpor.2018.02.002

Compas, B. E., Stoll, M. F., Thomsen, A. H., Oppedisan, G., EppingJordan, J. E., \& Krag, D. N. (1999). Adjustment to breast cancer: agerelated differences in coping and emotion distress. Breast Cancer Research, 54(3), 195-203. doi: 10.1023/ A:1006164928474

Danhauer, S. C., Douglas-Case, L., Tedeschi, R., Russell, G., Vishnevsky, T., Triplett, K.,...Avis, N. E. (2013). Predictors of posttraumatic growth in women with breast cancer. Psycho-Oncology, 22(12), 26762683. doi: $10.1002 /$ pon.3298

De Haro-Rodríguez, M. A., Gallardo-Vidal, L. S., Martínez-Martínez, M. L., Camacho-Calderón, N., Velázquez-Tlapanco, J., \& Paredes, E. (2014). Factores relacionados con las diferentes estrategias de afrontamiento al cáncer de mama en pacientes de recién diagnóstico. Psicooncología, 11(1), 87-99. doi: 10.5209/rev_PSIC.2014.v11.n1.44919

Dumalaon-Canaria, J. A., Trichard, I., Hutchinson, A. D., \& Wilson, C. (2018). Fear of cancer recurrence and psychological well-being in women with breast cancer: The role of causal cancer attributions and optimism. European Journal of Cancer Care, 27(1), 1-12. doi: 10.1111 /ecc. 12579

Dunnill, C. J., Al-Tameemi, W., Collett, A., Haslam, I. S., \& Georgopoulos, N. T. (2018). A Clinical and Biological Guide for Understanding Chemotherapy-Induced Alopecia and Its Prevention. The Oncologist, 23(1), 84-96. doi:10.1634/theoncologist.2017-0263

Elumelu, T. N., Asuzu, C. C., \& Akin-Odanye, E. O. (2015). Impact of active coping, religion and acceptance on quality of life of patients with breast cancer in the department of radiotherapy, UCH. BMJ Support Palliat Care, 5, 175-180. doi: 10.1136/bmjspcare-2012-000409. 
Eun, H. H., \& Young, K. C. (2014). The Mediating Effects of Self-Esteem and Optimism on the Relationship between Quality of Life and Depressive Symptoms of Breast Cancer Patients. Psychiatry Investigation, 11(4), 437-445. doi:10.4306/pi.2014.11.4.437

Falo, C., Villar, H., Rodríguez, E., Mena, M., \& Font, A. (2014). Calidad de vida en cáncer de mama metastásico de larga evolución: la opinión de las pacientes. Psicooncología, 11(2-3), 313-331. doi: 10.5209/rev_psic.2014.v11.n2-3.47391

Figueroa, M., Contini, N., Lacunza, A., Levin, M., \& Suedan, A. (2005). Las estrategias de afrontamiento y su relación con el nivel de bienestar psicológico. Un estudio con adolescentes de nivel socioeconómico bajo de Tucumán (Argentina). Anales de Psicología, 21(1), 66-72. Recuperado de http://revistas.um.es/analesps/article/view/27171

Finck, C., Barradas, S., Zenger, M., \& Hinz, A. (2018). Quality of life in breast cancer patients: Associations with optimism and social support. International Journal of Clinical and Health Psychology, 17, 27-34. doi: 10.1016/j.ijchp.2017.11.002

García-Torres, F., \& Alós, F. J. (2013). Identification of different depressive symptoms after mastectomy. Psycho-Oncology, 22(12), 2857-2859. doi: 10.1002/pon.3349

George, D., \& Mallery, P. (2003). Spss for Windows step by step: A Simple Guide and Reference. 11.0 Update (4. ${ }^{\mathrm{a}}$ ed.). Boston: Allyn \& Bacon.

Gómez, P., Bragado, C., \& Hernández, M. J. (2014). Psychological distress in women with breast and gynecological cancer treated with radical surgery. Psycho-Oncology, 23(4), 459-466. doi: 10.1002/pon.3439

González, M., Ibáñez, I., \& Barrera, A. (2017). Rumiación, preocupación y orientación negativa al problema: procesos transdiagnósticos de los trastornos de ansiedad, de la conducta alimentaria y del estado de ánimo. Acta Colombiana de Psicología, 20(2), 42-52. doi: http://www.dx.doi.org/10.14718/ACP.2017.20.2.3

Granero-Molina, J., Díaz, M. M., Márquez, J., Castro-Sánchez, A. M., López, O. M., \& Fernández-Sola, C. (2014). Religious faith in coping with terminal cancer: what is the nursing experience?. European Journal of Cancer Care, 23(3), 300-309. doi: 10.1111/ecc.12150

Hamama-Raz, Y. (2012). Does psychological adjustment of melanoma survivors differs between genders?. Psycho-Oncology, 21(3), 255-263. doi: 10.1002/pon.1889

Henneghan, A. M., Carter, P. Stuifbergan, A., Parmelee, B., \& Kesler, S. (2018). Relationships between self-reported sleep quality components and cognitive functioning in breast cancer survivors up to 10 years following chemotherapy. Psycho-Oncology, 27(8), 1937-1943. doi: 10.1002/pon. 4745

Hopman, P., \& Rijken, M. (2014). Illness perceptions of cancer patients: relationships with illness characteristics and coping. Psycho-Oncology, 24(1), 11-18. doi: 10.1002/pon.3591

Kangas, M. (2013). DSM-5 trauma and stress-related disorders: implications for screening for cancer-related stress. Frontiers in Psychiatry, 4(122), 1-3. doi: [10.3389/fpsyt.2013.00122]

Lan, M., Zhang, L., Zhang, Y., \& Yan, J. (2018). The relationship among illness perception, coping and functional exercise adherence in Chinese breast cancer survivors. Journal of Advanced Nursing, 1-10. doi: $10.1111 /$ jan. 13832

Morán, C., Landero, R., \& González, M. T. (2010). COPE-28: un análisis psicométrico de la versión en español del Brief COPE. Universitas Psychologica, 9 (2), 543-552. ISSN 1657-9267.

Ortiz, E., Méndez, L., Camargo, J., Chavarro, S., Toro, G., \& Vernaza, M. (2014). Relación entre las estrategias de afrontamiento, ansiedad, depresión y autoestima, en un grupo de adultos con diagnóstico de cáncer. Psychologia: Avances de la Disciplina, 8(1), 77-83

Park, C. L., Waddington, E., \& Abraham, R. (2018). Different dimensions of religiousness/spirituality are associated with health behaviors in breast cancer survivors. Psycho-Oncology, 27(10), 2466-2472. doi: 10.1002/pon. 4852

Pereira, M. G., Figueiredo, A. P., \& Fincham, F. D. (2012). Anxiety, depression, traumatic stress and quality of life in colorectal cancer after different treatments: a study with Portuguese patients and their partners. European Journal of Oncology Nursing: The official Journal of European Oncology Nursing Society, 16(3), 227-232. doi: 10.1016/j.ejon.2011.06.006

Philips, S. M., \& McAuley, E. (2015). Associations between self-reported post-diagnosis physical activity changes, body weight changes, and psychosocial well-being in breast cancer survivors. Support Care Cancer 23(1), 159-167. doi: 10.1007/s00520-014-2346-5

Pintado, S. (2017). Self-concept and emotional well-being in patients with breast cancer. Revista Iberoamericana de Psicología y Salud, 8(2), 76-84. doi: 10.23923/j.rips.2017.08.007

Ringwald, J., Wochnowski, C., Bosse, K., Giel, E., Schäffeler, N., Zipfel, S., \& Teufel, M. (2016). Psychological distress, anxiety, and depression of cancer-affected BRCA1/2 mutation carriers: a systematic review. Jour nal of Genetic Counseling, 25(5), 880-891. doi: 10.1007/s10897-016-9949-6

Robert, R., Torfinn, G., Roy, B., Olav, D., Arnstein, F., Sophie, D.,... Alv, A. (2010). A study of coping in long-term testicular cancer survivors. Psychology, Health \& Medicine, 15(2), 146-158. doi: 10.1080/13548501003623955

Rosen, A., Rodriguez-Wallberg, K. A., \& Rosenzweig, L. (2009). Psychosocial distress in young cancer survivors. Seminars in Oncology Nursing, 25(4), 268-277. doi: 10.1016/j.soncn.2009.08.004

Rosenberg, M. (1965). Society and adolescent self-image. Princenton, N.J: Princenton University Press. doi:_10.1515/9781400876136

Segura, M., García, R., \& Saúl, L. A. (2014). Imagen corporal y autoestima en mujeres mastectomizadas. Psicooncología, 11(1), 45-57. doi: 10.5209/rev_PSIC.2014.v11.n1.44916

Sun, L., Ang, E., Darryl, W. H., \& López, V. (2018). Losing the breast: A meta-synthesis of the impact in women breast cancer survivors. PsychoOncology, 27(2), 376-385. doi: 10.1002/pon.4460

Teo, I., Fingeret, M. C., Liu, J., \& Chang, D. W. (2016). Coping and quality of life of patients following microsurgical treatment for breast cancerrelated lymphedema. Journal of Health Psychology, 21(12), 2983-2993. doi: 10.1177/1359105315589801

Vargas, S., Herrera, G. P., Rodríguez, L., \& Sepúlveda, G. J. (2011). Confiabilidad del cuestionario Brief COPE Inventory en versión en español para evaluar estrategias de afrontamiento en pacientes con cáncer de seno. Investigación en Enfermeria: Imagen y Desarrollo, 12(1), 7-24.

Vázquez, A. J., Jiménez, R., \& Vázquez-Morejón, R. (2004). Escala de autoestima de Rosenberg: fiabilidad y validez en población clínica española. Apuntes de Psicología, 22(2), 247-255.

Yang, H., Brand, J. S., Fang, F., Chiesa, F., Johansson, A. L. V., Hall, P., \& Czene, K. (2016). Time-dependent risk of depression, anxiety, and stress-related disorders in patients with invasive and in situ breast cancer. International Journal of Cancer, 140(4), 841-852. doi: 10.1002/ijc.30514

You, J., Wang, C., Rodríguez, L., Wang, X., \& Lu, Q. (2018). Personality, coping strategies and emotional adjustment among Chinese cancer patients of different ages. European Journal of Cancer Care, 27(1), 1-9. doi: $10.1111 /$ ecc. 12781 